c/o The Zoological Society of London, Regent's Park, N.W. 1.

\title{
APPLICATION FOR MEMBERSHIP
}

I am interested in the work of the Society and should like to become a Member.

Name and Address (BLOCK LETTERS).

(Please state Mr., MIrs., Miss, or Title)

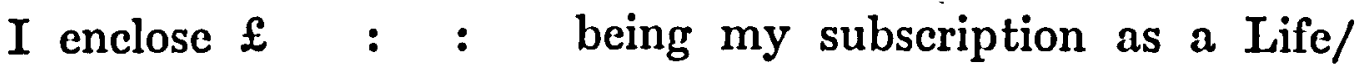
Ordinary Member.*

Please send me the following forms :-

Banker's Order. Deed of Covenant.

(Delete any of the above not applicable.)

* The annual subscription is $\mathfrak{1 1}$, payable on 1st January. The value of a subscription is almost doubled if it is paid under a 7-year Deed of Covenant. The cost to the member of doing this is nothing at all.

The use of a Banker's Order is suggested as it saves time and expense.

Life Mémbership Fee

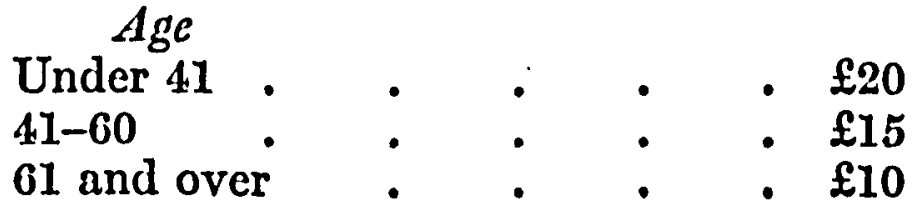




\section{THE}

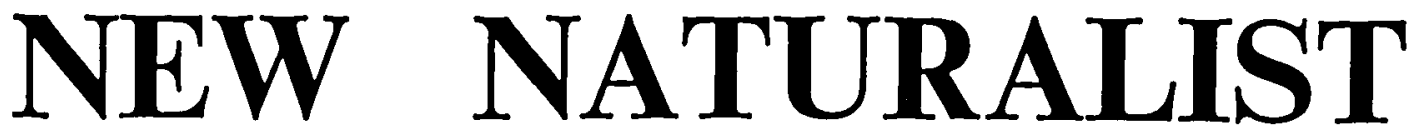

This year we celebrate the tenth birthday of a library that has, in that time, become famous. Almost fifty volumes on all aspects of Britain's fauna and flora have been published; a selection of which we have chosen for ORYX readers.

\section{British Mammals}

\section{Harrison Matthews}

"The editors' belief that this is probably the most important book on British Mammals ever published is almost certainly justified. It would be hard to overstate how well he has succeeded. The same impeccable standard of illustration is maintained here."-LIsTeNer. 156 illustrations, 16 in colour. 25s.

\section{The British Amphibians and Reptiles}

\section{Malcolm Smith}

"Scholarly, without ever being dull ; it gives complete life histories of every British species, with careful accounts of their structure and relationships." —ORSERVER

144 illustrations, 18 in colour. 21s.

\section{Birds and Men}

\section{E. M. Nicholson}

"The theme of this interesting and eminently readable book is the impact of civilization, whether rural or urban, upon British birds."- MIE TIMEs weEkLY EDN.

83 illustrations, 42 in colour. 21 s.

\section{Sea Birds}

James Fisher and R. M. Lockley

"Particularly useful and informative. This is the first time a comprehensive biological work on the birds of the North Atlantic has been made available to ornithologists in this country."-DRmIII DIRDs

132 illustrations. 25s.

\section{Man and the Land}

\section{Dudley Stamp}

"A book of endlessly fascinating detail illustrating both in text and in the excellent photographs the interaction of Man and the land."-rinanctar times

148 illustrations, 19 maps, ctc. 35s.

\section{A Natural History of Man in Britain}

$$
\text { H. J. Fleure }
$$

"An impressive exposition of human geography, by a great master ... a study of the changing relations between man and environment."-DLACKfriars 122 illustrations, 38 in colour. 21s. 
Qisit the
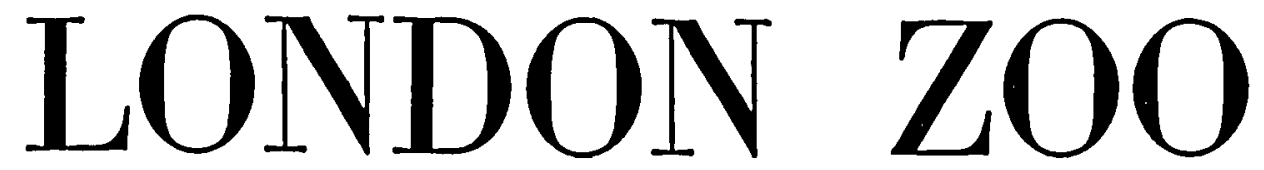

The most comprehensive collection of Animals in the World.

\author{
AMPLE PARKING GROUND \\ AQUARIUM - PHOTOGRAPHERS' PARADISE \\ ANIMIAL RIDES - . CHILDREN'S ZOO \\ REPTILE HOUSE - CHIMPANZEES' TEA PARTY \\ FULLEST CATERING FACILITIES (Fully Licensed)
}

* * *

OPEN DAILY

ist MArcil to 3ist Octoder • • 9 a.m.

ist Novemaer to 28tir Frbruary . 10 a.m.

Sundays 2.30 p.m. (to the General Public)

Crosing Trmes:-Sunset or 7 p.m. whichever is the eatlier

(Closed to the Public on Christmas Day)

Spccial floodlighting on Saturday cvenings until II p.m. during 1954 (June 12-Scpt. II).

ADMission: Adurts 2s. 6d. Cinldren half-price

Mondays (except Bank Holidays) Adults is. 6d., Cinldren, half-price

Batb Chairs and Cbildren's Pusb Cbairs can be bired, Cbarge 2s. all day (Deposit 2s. 6d.)

Particulars of Fellowship may be obtained from the Chief Clerk, Zoological Society's Offices,

Regent's Park, N.W. r. 


\section{ANIMAL PARADISE}

To animal lovers, the Kruger National Park must be the most enthralling place in the world: for it is the world's greatest game sanctuary $\ldots$ 8,000 square miles of wild bush country, where the untamed creatures of the African jungle may be seen at close quarters in absolute safety (provided you stay in your car). In addition, there is the Hluhlwe Game Reserve in Natal where the rare white rhino roams and a number of other large game reserves: from all of which you can 'bring 'em back alive', in your camera.

Yet all this is only part of the thrill of a holiday in the glorious sunshine and scenery of South Africa.

Every Thuirsday afternoon at $\mathbf{4 . 0}$ a Mailship sails from Southampton to South African sunshine

Also sailings from London

Full details and illustrated literature from Travel Agents or 3 Fenchurch Street, London, $E C_{3}$
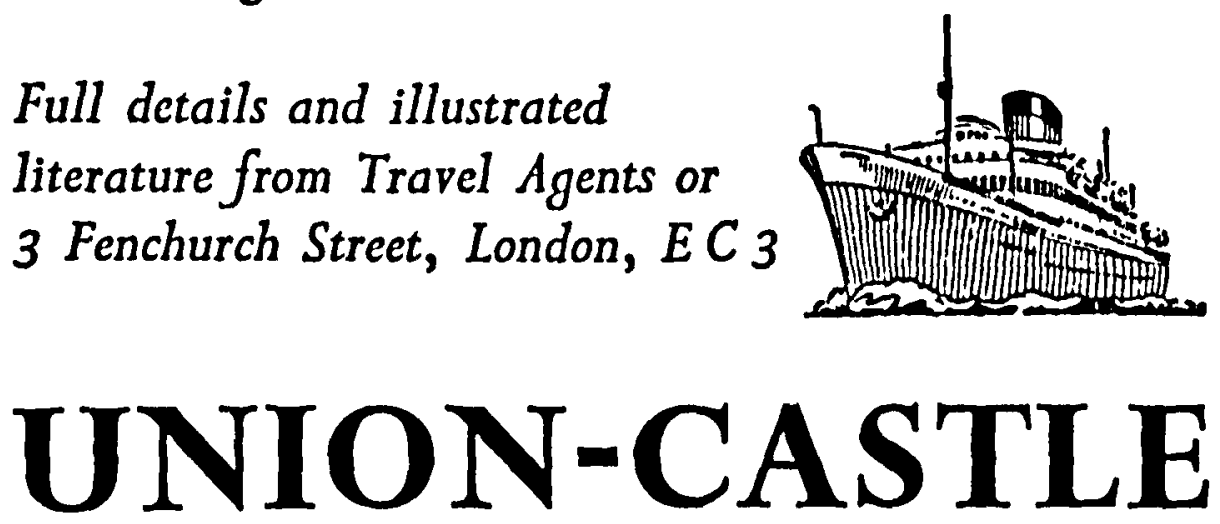

Carry you in comfort to the Cape 
STEPHEN AUBTIN AND SONS, TTMTTED, GENERAL AND ORIENTAL PRINTERS, HERTFORD. 